\title{
ENTERRAN DO HERÓIS, PATRIARCAS, SUICIDAS E TRAIDORES: SOLIDARIEDADE E OSTRACISMO NOS ANDES COLOMBIANOS
}

Santiago Alvarez

\section{Introdução}

Este artigo nasce de uma inesperada surpresa. Durante meu trabalho de campo nas montanhas colombianas, descobri funerais animados por bandas de mariachis mexicanos, ou melhor, por colombianos tocando como mariachis mexicanos. Dois fatos surpreenderam-me: que a música fosse mexicana e que fosse festiva. Ainda que este segundo aspecto seja um lugar-comum em etnografias sobre diversas culturas, experimentá-lo pela primeira vez não deixou de maravilhar-me. É justamente como uma tentativa de explicar esse fenômeno que reflito sobre diferenças e hierarquias observadas nos ritos fúnebres em uma comunidade camponesa dos andes colombianos. Nesse sentido, este trabalho está relacionado a observações e reflexões existentes desde a origem da disciplina antropológica sobre a presença, em tais ritos, de simbolismos festivos associados ao renascimento da vida (ver Bachoffen 1967; Frazer 1890; Hertz 1960; Bloch e Parry 1982). Interessam-me, em particular, as lúcidas observações de Robert Hertz sobre os ritos fúnebres. Hertz não se dedicou a uma simples descrição dos símbolos de renascimento encontrados nesses ritos, ou apenas a ressaltar a notável semelhança encontrada entre eles e os rituais de iniciação, mas sim, relacionou todos esses fenômenos à necessidade, em uma comunidade determinada, de se afirmar a perdurabilidade do social (Hertz 1960). Vinculando os ritos fúnebres à sociedade, mas tentando explicar a dinâmica e a complexidade dos rituais, gostaria de a partir deles analisar as formas seletivas de expressão da solidariedade social em uma determinada comunidade.

Neste estudo sobre ritos fúnebres nos andes colombianos, podemos observar alguns elementos - entre eles a introdução de bandas de mariachis - que constituem uma adaptação a mudanças sociais, a novas circunstâncias políticas e econômicas. Será que esses novos elementos - 
neste caso, relacionados à chegada dos narcotraficantes como grupo social ascendente (Alvarez 2001:49-73) - colocam em questão a persistência, nos rituais observados, de uma ideologia hierárquica que, como veremos, privilegia uma masculinidade agressiva? Há nos rituais, além de possíveis mudanças, elementos que permanecem inalterados e que constituiriam o que Maurice Bloch (1992: 1) denominou de estrutura mínima dos rituais?

A observação direta de mais de vinte funerais durante o período a que este trabalho se refere, permitiu-me perceber nessas cerimônias fúnebres notáveis diferenças quantitativas (presença maciça ou reduzida de pessoas) e qualitativas (introdução de mariachis). Essas diferenças estão associadas ao sexo e à posição social do morto, bem como à forma como se deu a morte. É por meio delas que a comunidade reinterpreta a vida do morto, construindo uma percepção social fixa sobre quem era ele no passado.

A comunidade, que para os fins deste artigo chamo de Nómeque, é habitada por cerca de três mil pessoas na sua área urbana. Encontra-se cravada no altiplano Cundiboyacense, próximo ao páramo de Sumapaz, a cerca de 2.600 metros de altitude e a cem quilômetros a sudeste de Bogotá. Nómeque se vê atingida por diferentes expressões de violência externa e interna. Várias famílias camponesas estão envolvidas em vinganças de sangue, em que ideais agressivos de masculinidade encontram sua trágica expressão. Por outro lado, uma palpável violência doméstica revela um conflito pelo controle do lar e prova a existência de tensões que são freqüentemente expressas na forma de abusos físicos ou verbais dirigidos contra mulheres e crianças. Além disso, diversos atores sociais - a guerrilha, os narcotraficantes, as Forças Armadas - lutam violentamente pelo controle da região. Durante o trabalho de campo em Nómeque, vários membros da comunidade envolvidos nesses conflitos foram mortos, propositalmente ou por acaso. Para fins de esclarecimento e levando em conta que a discussão em torno do significado da violência nos levaria à elaboração de um outro artigo, tentarei defini-la de modo a abarcar a totalidade dos fenômenos aqui descritos como violentos. Para tanto, recorro a David Riches que nos permite pensar em uma definição mínima, transcultural e válida de violência: " uma inflicção contestável de dano físico" (Riches 1988:28). 


\section{Os ritos fúnebres e o social}

Os ritos fúnebres costumam revelar mais sobre os vivos do que sobre os mortos. Expressam a percepção social de uma determinada comunidade diante da morte de um de seus membros, a qual se vê ameaçada em face da aparição do caos e da descontinuidade produzidos pela morte (Bloch e Parry 1982:4). Notemos que, para Hertz, o morto não é somente um indivíduo biológico, mas também um ser social esculpido no indivíduo físico cuja morte é pouco menos que um sacrilégio contra a ordem social (Hertz 1960:77; ver, também, Bloch e Parry 1982:4).

Os rituais fúnebres tendem a inverter essa circunstância negativa para a comunidade e a transformá-la, quando possível, em uma triunfante afirmação da perdurabilidade do social. É por isso que as cerimônias fúnebres, além de exprimirem sentimentos subjetivos, estão impregnadas de ações e representações coletivas. Tendemos a considerar as emoções expressas diante da morte como individuais ou pessoais. Hertz nos faz notar como os rituais organizam e manipulam essas emoções (Hertz 1960:28). Nesse sentido, Maurice Bloch e Jonathan Parry (1982:3) consideram o argumento de Hertz (sobre a expressão de emoções diante da morte de um ser próximo) análogo ao sustentado por Émile Durkheim em relação ao suicídio. Isto é, basicamente, que até o mais individual e subjetivo dos atos, o suicídio no caso de Durkheim - e no caso de Hertz, a expressão da dor pela morte do ser querido -, pode e deve ser compreendido em sua dimensão social. Essas ações aparecem como atos de total subjetividade mas, analisando-as detidamente, encontramos os inconfundíveis traços da sociedade.

Na comunidade analisada, a acentuação de diferenças de gênero emerge como uma estratégia central na construção de diferenças sociais. Desse ponto de vista, poderíamos dizer que uma representação agressiva do masculino é transformada em uma representação política, na medida em que expressa e justifica relações de poder (ver Alvarez 2001). Em Nómeque, essa representação se exprime nas práticas em que, como diria Michael Herzfeld, é necessário demonstrar "excelência na atuação", a capacidade para destacar a virilidade mediante façanhas que chamativamente "falam por si só" (apud Gilmore 1994:41). Quando nos referimos a uma representação de masculinidade não devemos deixar de levar em conta que, como dizia Henrietta Moore, se os discursos sobre sexualidade e gênero constroem os homens e as mulheres como tipos diferentes de pessoas, o interessante acerca dessas construções é que, freqüentemente, possuem uma relação apenas tangencial com as condutas, atribu- 
tos e imagens dos indivíduos - homens e mulheres (Moore 1994:138). A masculinidade deve ser entendida como um complexo processo de autoconstrução em relação aos outros, confrontando, ao mesmo tempo, representações culturais, nem sempre homogêneas, do que um homem deve ser (Wade 1994:115). As marcadas diferenças de gênero presentes nessa representação agressiva do masculino encontrada na comunidade são expressas também nos ritos fúnebres. Os homens violentos, quase monopolizadores da agressão física, recebem um tratamento seletivo por parte da comunidade, que reconhece neles um status especial atribuído àqueles que se supõe estarem a cada dia em contato com a morte.

Discuti em outros trabalhos as similaridades e diferenças entre essa masculinidade agressiva encontrada em Nómeque e as registradas em outras etnografias andinas, em particular nos casos de Peru e México (ver Alvarez 1998:49). As semelhanças são especialmente notáveis no fenômeno registrado nos andes peruanos, conhecido como gamonalismo. Os gamonales são mestiços imersos em uma sociedade com duas identidades, mestiça e indígena, que ocupam, mediante a violência, um espaço político de articulação entre a sociedade local e o Estado peruano (Poole 1994:5; Gose 1994:192). Sem querer alongar-me, encontro profundas semelhanças entre a construção performativa do homem agressivo no gamonalismo e o caso que aqui nos ocupa. No entanto, ao mesmo tempo, verifico grandes diferenças já que os gamonales constroem sua identidade mestiça em contraste e oposição aos indígenas, atuando como brokers sociais violentos entre a sociedade local e a nacional. No que se refere a Nómeque - sabendo dos limites implicados em toda síntese - , afirmo que a construção performativa dá-se entre supostos iguais em uma sociedade mestiça camponesa. Nela, a antiga estrutura hierárquica estava encabeçada pelos grandes proprietários. Uma bem-sucedida reforma agrária eliminou os patrões, mas não uma ideologia hierárquica e agressiva. Os camponeses, agora proprietários de minifúndios, competem entre si e os narcos (narcotraficantes) representam uma tentativa parcialmente exitosa de constituição de uma nova hierarquia social (ver Alvarez 1998:365).

Levando em conta essa masculinidade agressiva, é interessante notar que, na análise das cerimônias fúnebres, o contraste mais marcado percebido deu-se entre funerais de homens jovens mortos violentamente e funerais de mulheres que cometeram suicídio.

A morte trágica de homens jovens parece ser considerada uma oferenda altruística à comunidade (Bloch e Parry 1982: 16). Sua morte, que estaria catalogada como a boa morte por excelência, é percebida como uma imolação do indivíduo no altar do grupo social (Bloch e Parry 1982: 17). 
Relaciono essa oferenda de uma vida interrompida em benefício do grupo, com os estudos helenísticos de Jean Pierre Vernant sobre a morte do herói no campo de batalhas e o seu culto particular durante os tempos homéricos (Vernant 1990). Se a morte trágica dos homens é glorificada em Nómeque, as mulheres suicidas, ao contrário, são rejeitadas socialmente e condenadas pela comunidade. Como será visto, o suicídio aparece para esta como um ato inexplicável, quando, paradoxalmente, as constantes vendetas entre famílias são percebidas como parte do cotidiano. Nesse contexto, a morte por suicídio aparece como a má morte por excelência: o suicida atua sozinho, de maneira egoísta, e perde, para a sociedade, o seu poder regenerativo (Bloch e Parry 1982).

Poderíamos dizer que ambos os casos se encontram nos extremos das percepções sociais relacionadas à morte e que, de fato, estão nos extremos das diferenças observadas nos funerais dessa comunidade. Uma análise mais precisa dos dados coletados nos indicará que, se existe um claro contraste entre os dois, há também muitíssimos casos de cerimônias fúnebres em que as diferenças são menos contrastantes. Para uma melhor compreensão dos mesmos, sem querer ser esquemático, procuro estruturar o material dividindo-o em: funerais masculinos associados ao culto do herói; funerais masculinos associados à morte de importantes líderes políticos; funerais de suicídios femininos; funerais das pessoas mortas pela guerrilha; funerais de pessoas idosas, tanto mulheres quanto homens.

\section{As cerimônias fúnebres em Nómeque}

Freqüentar cerimônias fúnebres e participar delas talvez seja a atividade social mais importante em Nómeque. As pessoas da comunidade estão particularmente interessadas em freqüentar funerais. É considerada uma forma de expressar compaixão e, sobretudo, solidariedade. "Em Nómeque somos muito solidários com quem morre". "Estou aqui, porque tem que compartilhar a dor alheia". Gente de "terra fria" (da montanha), freqüentemente, se compara com gente de menos compaixão, de "terra quente", isto é, dos vales cálidos circundantes. Julga-se que em "terra quente", as pessoas estão menos interessadas nos outros e não comparecem quando um vizinho morre. Estive presente, por acaso, em um funeral em "terra quente" quando uma procissão fúnebre atravessou, da igreja até o cemitério, o calorento povoado onde me encontrava e, de fato, somente sete pessoas acompanhavam o caixão - o que em Nómeque seria inconcebível. 
O povoado de Nómeque possui um pequeno cemitério de apenas uma fanegada (menos de um hectare), situado a uns três quilômetros da praça central. A falta de espaço condiciona a localização desordenada das sepulturas. As famílias tentam situar os túmulos de seus parentes o mais próximo possível uns dos outros, mas, na maioria dos casos, conseguem apenas colocá-los em uma certa área, misturados com outros mortos. As famílias mais antigas e tradicionais costumavam enterrar seus mortos na paróquia, mas essa tradição foi logo proibida, além do que, quase todas essas famílias abandonaram o povoado há muito tempo atrás, tendo assim perdido relevância no presente. À exceção de alguns mausoléus muito velhos e arruinados, precariamente construídos, grande parte dos mortos foi colocada em modestas sepulturas, com uma cruz e uma inscrição, ou ainda, em covas muito mais humildes. Indagadas sobre a localização das sepulturas, as pessoas sempre negaram a existência de alguma diferença de status ou hierarquia na utilização de qualquer uma dessas formas de enterrar seus mortos. De fato, não pude perceber nenhuma ordem consistente na maneira como os mortos estão dispostos. Ao contrário, as pessoas queixam-se constantemente da desordem e da sujeira do cemitério. Essa desordem poderia ser facilmente comparada com a forma particular como as casas são construídas no povoado, seguindo a linha em ziguezague dos córregos que o atravessam e utilizando todo tipo de terreno. No entanto, e apesar de tudo, a igreja católica e a praça vizinha criam um centro no povoado através do qual as demais casas se relacionam. Em um lugar onde a velha classe de proprietários de terras foi substituída depois de uma bem-sucedida rebelião agrária que estabeleceu o minifúndio como principal forma de exploração agrícola, o cemitério e a disposição das sepulturas não mostram uma ordem hierárquica claramente estabelecida.

\section{Funerais masculinos associados ao culto do herói}

Os funerais descritos nesta seção foram objeto de cultos especiais por parte da comunidade e de uma massiva expressão de solidariedade. Refletem a importância dada pela comunidade a vidas e mortes consideradas merecedoras de peculiar reconhecimento. Os mortos, nesses casos, são sempre homens cujas vidas foram tragicamente interrompidas. Jean Pierre Vernant (1990) descreve, no seu estudo da Grécia antiga, os cultos diferenciados relativos à bela morte do herói. O autor analisa a idealizada morte no campo de batalha, sonhada pelos jovens guerreiros gregos nos tempos épicos da llíada. Heróicos guerreiros preferiam a vida curta e 
a glória eterna que a morte em batalhas lhes proporcionava, antes da obrigatória perda de sua força e virilidade, como conseqüência do irreversível processo de envelhecimento. Morrendo violentamente na fleur de la jeneusse, eles conseguiriam perdurar na memória das gerações futuras no auge de sua virilidade e beleza, inatingidos pela decadência da idade (talvez por isso, ainda lembramos de Aquiles ou de Guevara). Se nem todos os casos apresentados dizem respeito à morte de jovens, guardadas as consideráveis diferenças, acho interessante a analogia com a forma como os heróis gregos eram percebidos nos tempos homéricos.

Como já foi dito sucintamente, em uma região onde o poder é disputado entre o Exército, a guerrilha e os narcotraficantes existem famílias envolvidas em sangrentos ciclos de vingança. A maioria desses casos tem a ver com as relações estabelecidas com seus vizinhos imediatos por causa de terras ou por conflitos familiares posteriores a uma aliança matrimonial frustrada (o marido abandona o lar desprezando a mulher ou ela o abandona como conseqüência da violência doméstica a que é submetida). Em todos eles, as partes envolvidas preferem não fazer uso do aparelho de Estado e, sim, resolver suas disputas internamente, estabelecendo uma relação de ódio com seus inimigos (cf. Reichel-Dolmatoff 1961:195; Alvarez 1998: 123-160).

No dia 22 de janeiro de 1995, Nicolás Castro, um homem em torno de 40 anos, foi assassinado. Seu corpo foi velado dois dias em uma casa funerária de Sutagao, a cidade mais próxima, e enterrado na tarde do dia 24 no cemitério de Nómeque. Durante o velório, o corpo foi exposto aos olhares dos visitantes, vestido com seu melhor traje escuro. Dois grandes círios davam alguma luminosidade ao recinto, mergulhado na penumbra. Durante o velório, os parentes e amigos expressavam as condolências à viúva e aos filhos e contemplavam por uns minutos o cadáver. De tempo em tempo, a viúva ou outro parente recomeçava a lenta reza do terço. Aos visitantes eram oferecidos um copo de aguardente e sopa de galinha para quem quisesse.

Antes do enterro, uma missa foi celebrada pela alma do defunto, sendo assistida por cerca de 250 pessoas. O padre abençoou o caixão, encerrando ali sua participação no rito fúnebre. Posteriormente, entre 800 e 1000 pessoas seguiram a pé o cortejo até o cemitério. Alguns jipes levavam coroas de flores com os nomes das famílias que as doaram escritos em fitas púrpuras.

O cemitério situava-se, aproximadamente, a dois quilômetros da igreja. Uma banda de mariachis acompanhava o cortejo enquanto os homens da família Castro levavam o morto. Os açougueiros de Nómeque 
(essa era a profissão do morto) pagaram uma banda de mariachis e ofereceram-na à memória de seu colega. Cantaram canções que falavam da morte como: "Ninguém é eterno no mundo", uma canção muito popular no campo colombiano, que fala da nossa comum mortalidade e de como não adianta chorar porque ninguém acorda do sono profundo. Também cantaram "A cruz de madeira”, uma canção mexicana que, ao contrário, faz referência à necessidade de continuar rezando pelos nossos mortos. Os músicos cantaram e tocaram seus instrumentos até chegar à cova.

Segundo José Nasser, um vereador, e G uillermo Tapia, o coveiro, a introdução de mariachis nas cerimônias fúnebres é relativamente recente, não devendo ter mais de três anos. Para ambos, os traficantes de drogas e sua paixão pelos mariachis têm a ver com a origem desse costume. Como já foi indicado, estamos aqui na presença de um elemento acrescentado ao ritual fúnebre tradicional. A incorporação dos mariachis permite-nos entrar em contato com a historicidade dos rituais, com a sua estabilidade ou variabilidade ao longo do tempo. Sua inclusão modificaria radicalmente o ritual? Muito pelo contrário, encontramo-nos na presença de um fenômeno que acaba acentuando diferenças e hierarquias existentes, mantendo o cerne do ritual intacto (Bloch 1992: 1). Isto significa também a aparição e a rápida ascensão de um grupo social determinado: os narcotraficantes, compradores de terra e de cavalos que tentam imitar, nas suas práticas, a velha classe de proprietários de terras.

As mulheres abriram o caixão mostrando o morto, pela última vez, vestido no seu traje escuro, traje que os camponeses usam em ocasiões especiais, como casamentos e funerais. O trompete da banda tocou solenemente e as pessoas fizeram silêncio absoluto enquanto o caixão era colocado na sepultura. Foram as mulheres que depois, com seus prantos, quebraram o silêncio. Os participantes começaram a jogar flores na sepultura, a maioria delas tirada das coroas, enquanto os parentes próximos guardavam as inscrições em uma bolsa.

Posteriormente, na entrada do cemitério, em frente ao bar conhecido popularmente como La Última Lágrima, os parentes do finado ofereceram cervejas e refrigerantes aos presentes - não aceitar seria considerado um insulto. Durante todo esse tempo, os parentes masculinos mais próximos mantiveram-se juntos falando em voz baixa.

Estive em La Última Lágrima acompanhado por um camponês, casado com uma irmã do falecido. Os parentes mais próximos convidaram-no a se juntar ao círculo de homens. Ao nos aproximarmos, comentaram em voz baixa: "Isto não pode continuar assim, devemos fazer alguma coisa" e, inclusive, "É a segunda morte em um mês". Depois desses aconteci- 
mentos, os Castro começaram a se preparar para a vingança. Cada vez que eu passava pela porta do açougue da família, via um Castro praticando tiro com uma espingarda de ar comprimido. Eles faziam isso, não só como preparação, mas para mostrar a quem quisesse ver que não iriam permitir mais ataques ou afrontas.

A vingança consumou-se irremediavelmente: um Castro matou um Ramírez e sua jovem filha de aproximadamente 18 anos, ainda que preservando uma menina (a pequena neta) que os acompanhava. Os funerais dos Ramírez, mortos pelos Castro, foram diferentes dos funerais dos Castro assassinados pelos Ramírez. O velório aconteceu de modo reservado e restrito em uma capela na cidade mais próxima. Tive dificuldades para encontrar o local; quando finalmente cheguei, o cadáver já tinha sido levado para ser enterrado no cemitério de Sutagao, a cidade vizinha. Segundo um informante, só os parentes mais próximos participaram, acrescentando que os homens fizeram um juramento solene diante do altar, prometendo vingar os mortos. Um ônibus trouxe os parentes dos Ramírez ao cemitério. Os caixões foram levados em dois carros fúnebres e atrás deles três jipes transportaram os Ramírez e seus amigos. Muito pouca gente de Nómeque se fez presente, praticamente todos os participantes eram parentes que, de um modo ou de outro, se sentiam obrigados a participar. O número total, muito inferior ao registrado no enterro anterior, girava em torno de, no máximo, 300 pessoas. Os homens retiraram os caixões dos carros e começaram a caminhar em direção ao cemitério. $\mathrm{O}$ funeral prosseguiu em silêncio. Percebi uma grande tensão no ambiente, os Ramírez levavam os ataúdes com os rostos crispados, dando a impressão de que matariam tantos Castro quanto pudessem. Os homens não fizeram nenhuma manifestação externa de sua dor, só olhavam com raiva, controlando seus gestos e emoções, só as mulheres choraram.

Como no enterro anterior, os participantes jogaram flores no túmulo. A filha pequena da mulher assassinada, que tinha presenciado a morte da mãe, colocou um buquê de flores sobre a sepultura. Posteriormente, os parentes mais próximos ofereceram cerveja aos participantes.

G uillermo Tapia, o coveiro, é primo de segundo grau dos Ramírez. Tive a impressão de que ele não queria que eu presenciasse o funeral. Um dia antes, dissera-me que o funeral já tinha ocorrido; quando o encontrei depois, nem tentou se desculpar. Ele comentou que os Ramírez decidiram fazer o funeral em Sutagao porque consideravam que o povo tinha tomado partido dos Castro.

Guillermo, muito preocupado com a pouca presença da população de Nómeque no funeral, disse-me: “Eu disse aos Ramírez que as pessoas 
de Nómeque não eram seus inimigos, mas eles me responderam que, para eles, o povoado estava do lado dos Castro". Exceto por G uillermo e por outra pessoa vinculada também por laços de parentesco aos Ramírez, não encontrei ninguém conhecido entre os presentes que não fosse membro direto da família. Um ou dois rostos conhecidos, mas pouca gente do povoado propriamente dito.

Houve outro exemplo de funeral heróico em Sutagao, a principal cidade da região. Esse caso apresenta características particulares já que não se trata de uma comunidade camponesa, mas de uma cidade de mais de 30 mil habitantes, sendo o morto um esportista. Agustín Tamayo, um jovem campeão de ciclismo que participou em competições européias como o Tour de France, foi enterrado em Sutagao logo após sua morte trágica em um acidente na estrada, quando sua bicicleta foi atingida por um caminhão. Seu enterro, a despeito de suas particularidades, poderia ser considerado um funeral heróico por excelência.

Parecia que toda a cidade de Sutagao estava presente na igreja. Calculei cerca de mil pessoas na missa e uma multidão composta por cerca de 5 mil pessoas do lado de fora. $O$ padre fez um sermão em que praticamente incluía Agustín no panteão dos heróis da história colombiana. Segundo ele, a morte de Agustín não foi em vão, já que morreu pela Colômbia, em geral, e pela sua cidade, Sutagao, em particular.

O trajeto da catedral ao cemitério foi difícil pela quantidade de carros, ônibus e microônibus, todos cobertos com coroas de flores. Quando o cortejo chegou ao cemitério, muitas pessoas que já se encontravam ali agitaram seus lenços brancos. Uma enorme quantidade de flores foi jogada no seu túmulo e os mariachis cantaram inúmeras canções em sua homenagem.

Por que um ciclista passa a compor o panteão dos heróis? Suspeito que por sua morte prematura e trágica, o que faz com compartilhe esse destino com as vítimas da violência entre famílias, apesar de o seu caso ter profundas diferenças com os anteriores. Quanto às vinganças, elas consagram heróis faccionais, enquanto Agustín é um herói nacional. A poios diferenciados da comunidade, expressos no comparecimento aos funerais, também falam da existência de segmentos sociais distintos nessa comunidade rural. A relação do ciclista com Nómeque, por sua vez, é apenas tangencial, uma vez que Agustín Tamayo era casado com a filha de um camponês relativamente rico da comunidade. 


\section{Funerais de patriarcas}

Esta seção descreve a morte de patriarcas que estiveram envolvidos em atividades políticas decisivas no Partido Comunista, no movimento guerrilheiro e no movimento agrário durante a luta camponesa pela terra. Houve certa tensão na interpretação de suas vidas e o uso dos mariachis foi rejeitado pelos membros do Partido Comunista.

Quarta-feira, 1o de fevereiro de 1995, Pedro Guerrero, presidente da Câmara de Vereadores do povoado, distinto membro do Partido Comunista e antigo líder do movimento camponês, morre em um hospital em Bogotá aos 60 anos de idade, enquanto recebia tratamento para controlar o diabetes. Seu cadáver chegou a Nómeque nessa mesma tarde. Uma centena de simpatizantes esperava por ele na praça principal. Margarita Moreno e suas irmãs, membros de uma proeminente família comunista, estavam vestidas de preto e com lágrimas nos olhos. Vinte automóveis, fazendo soar suas sirenes, anunciaram a chegada do corpo, que foi velado no modesto salão da Câmara Municipal. O caixão tinha uma janela de vidro através da qual o morto podia ser observado no seu traje preto.

Praticamente todas as autoridades de Nómeque e todos os membros relevantes dos diferentes partidos políticos, os liberais, os comunistas e os conservadores se fizeram presentes para dar suas condolências à família do morto. Muitos camponeses com suas ruanas* formaram fila para ver o cadáver pela última vez. Enquanto aguardavam sua vez no salão, as pessoas bebiam grandes quantidades de aguardente de cana.

No dia seguinte, ao meio-dia, uma missa católica foi celebrada pelo descanso da alma do líder comunista. Por causa do número impressionante de pessoas reunidas - mais de mil - a missa ocorreu na praça principal. A banda de música da Escola Normal deu início à homenagem, entoando estrofes do hino nacional colombiano. O caixão foi coberto por uma bandeira vermelha com a foice e o martelo. O padre, diante do féretro coberto com a bandeira comunista, afirmou que não havia nada mais valoroso do que dar a vida pelos amigos, e que ainda existiam pessoas que faziam isso nesses tempos. Lembrou atitudes do morto com os pobres e para com as pessoas que necessitavam de sua ajuda. Depois disso, discursaram o novo chefe do Partido Comunista e o prefeito local.

Pedro Guerrero foi enterrado no cemitério de Sutagao. À uma hora da tarde, uma caravana de mais de cinqüenta automóveis, cobertos de

\footnotetext{
* N.T. - Ruana é uma espécie de manta de lã, vestimenta masculina típica do camponês colombiano (como um poncho aberto).
} 
coroas de flores, escoltou o caixão até a cidade que ficava a cerca de 30 minutos de distância por estrada. A caravana deteve-se na catedral, onde membros do Partido Comunista e parentes transportaram o caixão a pé até o cemitério.

Uma banda de mariachis esperava na entrada do cemitério para tocar. Alguns indivíduos não consideraram apropriada a presença de mariachis nesse enterro, associando-a a pessoas assassinadas e narcotraficantes. "Pedro Guerrero era uma pessoa pacífica e respeitável”, disseme Teófilo Zambrano, "Não creio que ele tivesse gostado de saber que uns mariachis iriam tocar no seu funeral. A música mexicana é para analfabetos, pessoas de classe baixa" . Na sua opinião, os mariachis são usados só em funerais masculinos, quando alguém é assassinado ou o morto é um indivíduo importante. Por outro lado, outras pessoas disseram que "a mais bela e cara das coisas que alguém pode oferecer é uma seresta e, se não foi feito em vida, pode ser oferecida quando a pessoa já está morta".

Quando o caixão chegou ao cemitério coberto pela bandeira comunista e carregado, os mariachis começaram a cantar. Tocaram "A cruz de madeira" e "Ninguém é eterno no mundo", que já conhecíamos do seu repertório. Mais uma vez, quando concluída a cerimônia, flores foram jogadas na sepultura. Uma importante figura nacional do Partido Comunista tomou a palavra para despedir-se do companheiro, e fez um discurso convencional sobre o comunismo, sua luta, a luta do movimento camponês e pela libertação. Apontou Pedro Guerrero como exemplo de luta e conduta revolucionária. Finalmente, gritou: "companheiro Pedro Guerrero", e as pessoas responderam, " presente", e novamente: "companheiro Pedro Guerrero", " presente”, e por último: “até quando?”, e as pessoas responderam: "eternamente". Nem todos os presentes ao enterro assistiram a esses discursos, somente os vinculados ao partido.

Em seguida, outro grupo de músicos fez sua aparição, era uma dupla de violonistas, vestidos com jaquetas pretas, de mais ou menos 20 anos. A partir desse momento, eles e os mariachis alternaram-se em uma espécie de desafio, tocando uma canção de cada vez. Os mariachis repetiram seus sucessos, acrescentando a popular canção do compositor brasileiro Roberto Carlos, "Tu és meu amigo da alma". Já o outro grupo, cantava canções de conteúdo político, como "Comandante Che Guevara", e também algumas canções folclóricas colombianas (pareciam, de fato, ser os cantores oficiais do Partido Comunista Colombiano). Depois de algum tempo, as pessoas começaram a sair do cemitério, momento em que, como de costume, foram oferecidos cervejas e refrigerantes. 
Em outra ocasião, encontrei Margarita Moreno muito triste depois de voltar de Sibate, um povoado próximo, onde seu tio, Dom Plácido Moreno, havia sido enterrado. Então presidente do Conselho local, tinha morrido em um acidente de carro. Margarita comentou, não sem orgulho, que trinta coroas de flores foram enviadas à sua família.

Uma banda de mariachis também tocou no seu funeral. “Já sabes agora desse costume pelo qual, se o morto gostava de duas ou três músicas quando vivo, os mariachis as cantarão no funeral. Antes, as pessoas cantavam canções religiosas. Eu não gosto da música festiva num enterro. Como no funeral de Pedro G uerrero, quando os músicos tocaram rancheras até a noite."

\section{Suicídios femininos}

Como já foi visto, o suicida comete um crime contra a sociedade e sua morte é considerada uma afronta à comunidade (Bloch e Parry 1982). Os dois casos de suicídio cujos funerais observei - ambos femininos - mostram que esses atos encontram uma forte rejeição social. A solidariedade expressa nos funerais limitou-se ao mínimo, estendendo-se somente aos parentes e amigos mais próximos. Em um dos casos, inclusive, os parentes masculinos tiveram, conscientemente, um comportamento pouco respeitoso durante a cerimônia fúnebre.

No estudo etnográfico que Gerardo e Alicia Reichel-Dolmatoff realizaram em Aritama, comunidade camponesa mestiça em Sierra Nevada de Santa Marta, é possível encontrar uma descrição dos suicídios em que também aparece ressaltado o caráter majoritariamente feminino dos mesmos. De fato, durante a permanência deles no campo, as mulheres foram as únicas a cometer suicídio. Os Dolmatoff foram inclusive informados de que os homens raras vezes se suicidam, ainda que alguns exemplos no passado tenham ocorrido (Reichel-Dolmatoff 1961:405). Orlando Fals Borda, em seu estudo de Saucío, um povoado da savana de Bogotá, trata da rejeição social ao suicídio e de sua raridade - o único caso que seus informantes puderam lembrar foi, curiosamente, o de uma jovem abandonada por seu amante (Fals Borda 1962:213).

Para os Reichel-Dolmatoff, de modo geral, o que levava as pessoas a cometer suicídio em Aritama eram conflitos familiares, ciúmes, morte de parente querido, agressão física por parte do marido ou humilhações e insultos sofridos de vizinhos ou familiares (Reichel-Dolmatoff 1961:405). O primeiro caso de suicídio que analisarei faz referência a algumas dessas causas. 
No dia 4 de fevereiro de 1995, Mariana de Reinal, uma mulher de apenas 35 anos, foi enterrada. Cometeu suicídio depois de ter contínuos problemas com seu marido e, especialmente, com sua sogra. Aproximadamente quarenta pessoas compareceram ao cemitério. Não houve missa antes do enterro e a cerimônia transcorreu em silêncio.

G uillermo Tapia, o coveiro, conversou com a mãe da morta. A mulher estava muito triste pela baixa freqüência ao funeral e perguntava-se o porquê. G uillermo disse-lhe que as pessoas não gostavam do que sua filha tinha feito. Comentou, então, comigo que cometer suicídio era uma ação terrível e que não podia entender como alguém podia fazer isso diante da beleza da vida. Segundo ele, "antes dos concílios" (fazendo provável referência ao Concílio Vaticano II), os suicidas não estavam autorizados a ser enterrados em campo-santo, isto é, na terra consagrada do cemitério, nem a ter nenhum tipo de "honra fúnebre". "Hoje em dia a situação mudou e as pessoas enterram os suicidas em campo-santo”.

“Dona Mariana [continuou] era do tipo que tornava a vida do marido impossível. Sempre andava procurando briga. Ela era professora e teria deixado o marido e ficado com os filhos. Inclusive, se os meninos tivessem que ficar com o marido, que é o que tem direitos, ela seria capaz de deixar os filhos e a casa. Todos teríamos esperado a agressão do seu marido, cansado de suportar essa situação, no entanto, foi ela quem se suicidou."

Elisabeth Bronfen, nos seus estudos sobre morte, feminilidade e estética (Bronfen 1992), propõe uma interessante abordagem das causas do suicídio feminino. Do meu ponto de vista, no entanto, Bronfen possui uma ligeira tendência a reduzir os corpos femininos a textos. A autora considera que a escolha da própria morte emerge de uma estratégia na qual escrever no próprio corpo seria uma maneira de libertar-se da opressão ligada ao corpo feminino. O suicídio, nesses casos, serviria como forma extrema de crítica àquelas atitudes culturais que reduzem o corpo feminino à posição de dependência e passividade, construindo-o como objeto vulnerável de incursões sexuais. O suicídio feminino, segundo a autora, poderia servir como metáfora para uma estratégia de escrita feminina no quadro dos opressivos padrões da cultura patriarcal (Bronfen 1992: 142).

No segundo caso de suicídio cometido durante minha estada no campo, uma jovem de 17 anos, Olga Fernández, foi encontrada morta no rio. Olga era epilética, não tinha comido nem falado com ninguém nos últimos dias. Mario Tapia (o irmão de Guillermo) pensou que se tratava de suicídio, ainda que outras pessoas próximas à família negassem esta versão. 
O funeral de Olga foi particularmente interessante pelos conflitos que marcaram a cerimônia. Menos de oitenta pessoas estiveram presentes. Os homens carregaram o caixão até o cemitério, onde ocorreu uma briga que degenerou em violência física entre o coveiro (o irmão de G uillermo) e um parente da jovem falecida. O motivo, tudo indica, teria sido que o coveiro não estaria fazendo seu trabalho de forma adequada. De fato, ele não conseguia colocar o caixão na cova porque não tinha calculado corretamente seu tamanho. Ele tornou a cavar no momento em que as irmãs da falecida estavam chorando desconsoladamente. Uma delas começou a cantar "A mor eterno" . A música fala de recordar eternamente o ser amado e desejar que os olhos deste não se fechem para sempre. Nessa hora, o coveiro interrompeu, caçoando da cantora e da morta. Quando a música falou de amor eterno, ele disse: " mas, nesse momento, ela está coberta de terra”, e ainda, “ninguém se lembrará dela”. Enquanto ele dizia essas coisas, vários parentes masculinos da morta riam das piadas. As mulheres pareciam empenhadas em construir uma atmosfera de respeito, enquanto muitos homens negavam essa possibilidade e participavam da subversão desse espírito. E assim foi, até o momento em que as bebidas foram oferecidas aos participantes.

\section{Funerais de pessoas mortas pela guerrilha}

A morte de pessoas executadas pela guerrilha não é percebida como heróica pela comunidade. A aprovação implícita das ações da guerrilha e o medo que elas produzem têm influência direta na escassa presença de pessoas nesses funerais. Em um desses casos, no entanto, a presença no funeral foi maciça e os rostos crispados refletiram uma reação de oposição ao que foi considerado uma injustificada decisão da guerrilha de matar esse indivíduo em particular. De qualquer forma, em nenhuma dessas ocorrências, os mortos receberam o tratamento especial observado nos casos comentados no início do artigo, nem sequer nos casos em que os mortos eram jovens.

José Vargas Herrera foi morto pela guerrilha, acusado de roubar gado. Tinha somente 24 anos. Segundo G uillermo, pouca gente compareceu ao enterro - menos de cem pessoas. Obviamente, não houve nenhuma música no funeral. Os mariachis, comentava-se, não poderiam estar presentes nessas situações.

José Muñoz também foi morto pela guerrilha, acusado de ser informante e ladrão. Foi enterrado na cidade. Não houve sequer aviso fúne- 
bre (cartazes colocados nos lugares centrais do povoado). Em vez disso, anunciou-se uma só vez pelo megafone da paróquia para dizer que o funeral se realizaria naquela tarde, em Sutagao. Apenas os parentes mais próximos compareceram.

Como terceiro exemplo, Luis Alberto Romero Pardo, de 40 anos, foi assassinado pela guerrilha às vésperas do Natal, no dia 23 de dezembro. Justiçaram-no por considerá-lo um informante dos militares, pois havia sido visto em público falando com um tenente-coronel do exército colombiano. Foi enterrado no dia seguinte. A festa popular, celebrada na praça, mesmo lugar onde o corpo de Luis Alberto foi baleado, somente foi interrompida por alguns minutos, tempo em que o ataúde contendo seus restos saiu da igreja e chegou ao cemitério. Seus familiares carregaram à mão o caixão, enquanto a multidão que celebrava o Natal fez, com dificuldade, silêncio. Duzentas pessoas acompanharam o caixão em silêncio com rostos sérios, cheios de raiva. Os homens foram andando na frente, levando o ataúde. As mulheres seguiam entoando novenas pela alma do defunto. Quando o caixão foi colocado no túmulo, as pessoas cantaram "Tu és meu amigo da alma".

\section{Funerais de pessoas idosas}

Nesta seção serão analisados funerais de idosos, mortos de causas naturais. Nenhum deles era considerado politicamente poderoso pelos membros da comunidade. Os dois funerais usados como exemplo apresentam cerimônias mais simples e despojadas e, em geral, desprovidas das tensões descritas em algumas das cerimônias anteriores. Trata-se de funerais femininos e masculinos que contaram com a presença maciça da comunidade que, assim, expressou seu respeito pelos velhos.

Na quarta-feira, 21 de junho de 1995, Blanca Giménez de Castillo, uma mulher de mais de 70 anos, foi enterrada no cemitério de Nómeque. Um ancião comentou que a falecida tinha sido uma grande pessoa, tendo cuidado de sua mãe quando ela estava doente. De acordo com seus familiares, ela morreu de morte natural, deixando vários filhos e netos. $\mathrm{O}$ padre celebrou a missa, mas só acompanhou o ataúde até a entrada da igreja. Os parentes masculinos carregaram o caixão até o cemitério, enquanto cerca de quatrocentas pessoas o escoltavam. Ninguém cantou canções, mas uma de suas filhas leu um poema em sua homenagem. Muitas mulheres, com lágrimas nos olhos, choraram e gritaram quando o cadáver de Blanca Giménez foi colocado na tumba. A maioria dos paren- 
tes masculinos manteve-se, nesse momento, atrás da sepultura, fumando e conversando em voz baixa. Somente os parentes masculinos mais chegados cercaram o caixão junto com as mulheres. Os parentes mais próximos trouxeram cervejas e refrigerantes para os presentes.

Na quinta-feira, 29 de junho de 1995, G ermán Romero, um camponês das terras altas de Nómeque, foi enterrado. Morreu com 103 anos de idade. A maioria das cerca de 350 pessoas presentes eram camponeses das terras altas, de Zaldúa, sua região de origem. Sobreviveram a ele sua mulher, suas filhas e vários netos. "Dom G ermán”, comentou um camponês, " morreu de 'morte natural' aos 103 anos. Que mais se pode esperar da vida?" As manifestações de dor foram mínimas. Ninguém, nem sequer suas filhas, estava particularmente triste, porque ele havia morrido muito bem em sua própria cama. Assim que foi posto na cova, sem música, foram jogadas flores e, posteriormente, oferecidas bebidas aos presentes.

\section{Conclusões}

A comunidade, através de diferenças qualitativas e quantitativas nos ritos fúnebres, julga o significado social do morto e de sua morte. Ela expressa seletivamente, com sua solidariedade, um julgamento social acerca do defunto. Oferecer um enterro particular ao morto reflete uma interpretação de sua vida e de sua morte. Vidas ambíguas e indeterminadas, como costumam ser a da maioria dos mortais, ficam, no entanto, permanentemente fixadas e julgadas por meio da interpretação irreversível dos funerais. Nesse sentido, Katherine Verdery indica-nos que um cadáver está cheio de sentidos, não por si mesmo, mas pelas relações culturais estabelecidas e pela forma com que a morte específica de uma pessoa é socialmente construída (Verdery 1999:28).

A introdução de bandas de mariachis constitui um fenômeno que demonstra a maleabilidade dos rituais e suas modificações históricas. No entanto, pelo menos nos casos observados, encontramos elementos centrais que permanecem inalterados e que, no meu modo de ver, constituem o que Maurice Bloch denominou de estrutura mínima ou o cerne dos rituais (Bloch 1992: 1). Esses elementos centrais dão conta da persistência de uma ideologia hierárquica que privilegia uma masculinidade agressiva (Alvarez 2001:49-73).

As mortes de patriarcas políticos e de homens falecidos tragicamente podem ser relacionadas entre si. A participação e o comportamento das pessoas nesses casos são similares. De fato, um homem morto tragi- 
camente pode ser transformado em herói e obter um reconhecimento comparável ao de uma venerável figura política. Esses casos estão em franco contraste com a participação e o comportamento da comunidade nos suicídios, que durante minha estada na comunidade foram sempre femininos e fortemente rejeitados socialmente. Idéias de comunidade e de gênero entrelaçam-se para condenar o suicídio feminino como um ato de egoísmo extremo. No entanto, alguns familiares próximos, particularmente mulheres, tentaram demonstrar respeito pelas mortas. Por que, então, os homens em um desses funerais trataram de zombar da solenidade do ritual? Na verdade, eles tentavam conter a difusão da interpretação mais óbvia do suicídio: suicidando-se, a mulher estaria acusando sua família e, em particular, à de seu marido pela sua morte. Dessa forma, a autoridade masculina era posta em risco e o comportamento dos homens no funeral pode ser compreendido como uma resposta a esse risco. As mulheres, por outro lado, colocavam-se na posição da suicida e, compassivas, tentavam acusar os homens pelo seu comportamento. Tratava-se de uma pequena batalha pela interpretação dessa morte. A despeito da resistência, a interpretação masculina foi a predominante.

Um elemento comum a todos os funerais é a comensalidade expressa no consumo de bebidas alcoólicas e refrigerantes oferecidos na saída do cemitério. Se este é um elemento presente em todas as cerimônias observadas, encontro nessa prática marcadas diferenças de gênero. É necessário assinalar que os homens eram consumidores quase exclusivos de álcool, enquanto correspondia às mulheres o consumo majoritário de refrigerantes.

O julgamento negativo por parte da comunidade, além do medo, contribuiu para interpretar os executados pela guerrilha muito mais como vilãos que como heróis. Eles foram condenados socialmente e receberam funerais com mínima participação popular. No entanto, quando uma dessas mortes foi considerada injusta, a participação da comunidade no enterro foi maior.

A análise dos funerais mostra-nos, portanto, que a comunidade de Nómeque constrói uma interpretação do morto que é expressa nos enterros. Uma morte violenta, quando é considerada altruísta, pode elevar uma pessoa à categoria de herói ou mártir, cuja memória será honrada pela comunidade. Ao mesmo tempo, uma má morte pode determinar a rejeição social e o esquecimento do significado de toda uma vida. 
Recebido em 22/3/01

Aprovado em 28/6/01

Tradução: Maria José Alfaro Freire

Revisão Técnica: Federico Neiburg e Marcela Coelho de Souza

Santiago Alvarez é doutor em antropologia pela London School of Economics, e professor do mestrado em Antropologia Social da Universidade Nacional de San Martín. É autor, entre outros artigos, de "Fundamentalismo Livrepensante" (2000) e "El Poder Masculino de la Violencia en los Andes Colombianos" (2001). 


\section{Referências bibliográficas}

ALVAREZ, Santiago. 1998. The Relationship between Internally and Externally Generated Violence in an Andean Mestizo Colombian Community. Ph.D. Thesis, London School of Economics. . 2001. "E1 Poder Masculino de la Violencia en los Andes Colombianos". Revista Avá, no 3, Universidad Nacional de Misiones.

BACHOFFEN, J. J. 1967. Myth, Religion and $M$ other Right. London: Routledge and Kegan Paul.

BLOCH, Maurice. 1992. Prey into Hunter. The Politics of Religious Experience. Cambridge: Cambridge University Press.

_ e PARRY, Jonathan. 1982. "Introduction”. In: M. Bloch e J. Parry (eds.), Death and the Regeneration of Life. Cambridge: Cambridge University Press.

BRONFEN, Elisabeth. 1992. Over her

Dead Body. Death, Femininity and the Aesthetic. Manchester: Manchester University Press.

FALS BORDA, Orlando. 1962. Peasant Society in the Colombian Andes: A Sociological Study of Saucío. Gainesville, F1.: University of Florida Press.

FRAZER, James. 1890. The Golden Bough. London: MacMillan.

GILMORE, David. 1994. Hacerse Hombre. Concepciones Culturales de la $\mathrm{M}$ asculinidad. Barcelona/Buenos Aires/México: Paidós.

GOSE, Peter. 1994. Deathly Waters and Hungry Mountains: Agrarian Ritual and Class Formation in an Andean Town. Toronto: University of Toronto Press.

HERTZ, Robert. 1960. “A Contribution to the Study of the Collective Representation of Death". In: Death and the Right $\mathrm{H}$ and. London: Cohen and West.

MOORE, Henrietta. 1994. “The Problem of Explaining Violence”. In: P. Harvey e P. Gow (eds.), Sex and Violence. Issues in Representation and Experience. London/New York: Routledge. pp. 138-155.

POOLE, Deborah (ed.). 1994. Unruly Order: Violence, Power and Cultural Identity in the High Provinces of Southern Peru. Boulder/San Francisco/Oxford: Westview Press.

REICHEL-DOLMATOFF, Gerardo e Alicia. 1961. People of Aritama. The Cultural Personality of a Colombian Mestizo Village. Chicago: The University of Chicago Press.

RICHES, David. 1988. El Fenómeno de la Violencia. Madrid: Ediciones Pirámide.

VERDERY, Katherine. 1999. The Political Lives of Dead Bodies, Reburial and Postsocialist Change. New York: Columbia University Press.

VERNANT, Jean Pierre. 1990. “A Beautiful Death and the Disfigured Corpse in Homeric Epic”. In: F. Zeitlin (ed.), M ortals and Immortals. New York/London: Mythos.

WADE, Peter. 1994. "Man the Hunter". In: P. Harvey e P. G ow (eds.), Sex and Violence. Issues in Representation and Experience. London/New York: Routledge. pp. 115-137. 


\section{Resumo}

Este artigo discute diferenças e hierarquias encontradas nos ritos fúnebres de uma comunidade camponesa na região sudeste dos andes colombianos. Nessa comunidade - afetada por diferentes expressões de violência -, os funerais emergem como formas seletivas de manifestação de solidariedade social. De fato, na população analisada foram observadas notáveis diferenças quantitativas e qualitativas na organização e evolução de tais cerimônias fúnebres. As diferenças estão relacionadas ao sexo e à posição social do morto, bem como à forma pela qual ele ou ela morreu. Em um extremo das representações e práticas sociais relacionadas à morte encontram-se os enterros de homens jovens, mortos tragicamente. Estes são objeto de um culto particular, sendo glorificados pela comunidade. No outro extremo, a comunidade expressa sua rejeição às mulheres suicidas, rejeição que se coloca em evidência, especialmente, durante a evolução dos funerais.

Palavras-chave Ritos Fúnebres, Masculinidade, Rituais, Violência, Colômbia

\section{Abstract}

This article discusses the differences and hierarchies found in the funeral rites of a peasant community in the southwestern region of the Colombian Andes. In this community - affected by different expressions of violence - funerals emerge as selective forms for the manifestation of social solidarity. In the population considered, marked qualitative and quantitative differences in the organization and evolution of these funeral rites were, in fact, observed. The differences are related to the sex and social position of the deceased, as well as to the way in which he or she died. At one extreme of the social practices and representations associated with death are the burials of young men killed tragically. These are the object of a particular cult, and are glorified by the community. At the other extreme, the community expresses its rejection of women who have committed suicide, an attitude which is particularly evident during the course of the funeral.

Key w ords Funerary Rites, Masculinity, Ritual, Violence, Colombia 